\title{
Accessing E-books through Academic Library Web Sites
}

\section{Andrea Dinkelman and Kristine Stacy-Bates}

\begin{abstract}
This article examines access to electronic books as provided on the Web sites of academic libraries in the Association of Research Libraries (ARL). Our goal was to discover the ways in which that access occurs and to analyze the merit of the various approaches. We found some common barriers to access, as well as many cases of exemplary access. Many libraries could improve access to e-books by providing guidance to the content of e-book packages, by including the word "book" in links from the homepage to the pages that provide e-books, by providing a one-step limit to e-books in the catalog, by explaining which types of resources are available through search structures outside the catalog, and by featuring e-books in library publicity and instruction.
\end{abstract}

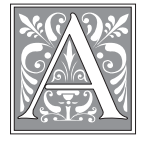

s electronic books grow in importance as library resources, individual e-books and ebook packages represent a large investment of collection funds and librarians' selection and cataloging time. For libraries to make the most of this investment, electronic books should be easy for patrons to use through library Web sites. The literature on e-books and on library Web site design suggests criteria for access through Web sites. The authors investigated access to electronic books as provided on the Web sites of academic libraries in the Association of Research Libraries. Our goal was to discover the ways in which that access occurs and to analyze the merit of the various approaches. In this article, we report our findings and provide suggestions for improving access to e-books on library Web sites.

\section{E-books Overview}

Especially in academic libraries, e-book collections are built around titles that are Web-accessible. Online e-books work with libraries' and patrons' desktop computers, laptops, and other existing hardware; they also fit logically with other electronic collections. A definition from a 2002 article typifies librarians' current view of e-books: "any piece of electronic text regardless of size or composition (a digital object), but excluding journal publications, made available electronically (or optically) for any device (handheld or desk-bound) that includes a screen."1

While electronic books lack the tactile appeal and some traditional advantages of their print counterparts, they can provide increased convenience and useful features unique to the electronic medium. Remote access and the possibility for multiple patrons at once to use electronic refer- 
ence products increase the availability of reference materials. ${ }^{2}$ A great advantage to e-books is the ability to search the full text with more speed and versatility than when perusing print, particularly the ability to search within aggregated collections of electronic books. ${ }^{3}$ This feature is already taken for granted by most Web-acclimated patrons, who have high expectations for searching all electronic material, while librarians appreciate the progress this represents for reference service. ${ }^{4}$ Internal hyperlinking and more frequent updating of content add to electronic books' appeal, and e-books can also be usefully linked with other library resources, such as the catalog or a metasearch engine. ${ }^{5}$

Several works provide notable overviews to e-book issues. Lucia Snowhill considers nearly all factors in implementing electronic books for libraries, with the most emphasis given to elements that factor into purchase decisions. Snowhill also reports on a survey carried out by the Ebook Task Force of the University of California's California Digital Library in 2001, which showed a group of libraries in the trial stage of working with e-books. ${ }^{6}$ Stuart D. Lee's 2002 book on electronic collection development comprehensively covers the details of purchasing and implementing electronic resources of all types, including e-books. ${ }^{7}$ Chennupati K. Ramaiah provides a comprehensive bibliography about e-book publishing trends, implementation and usage in libraries, and e-book interface design. ${ }^{8}$ Putting e-books into context in another way, Michèle V. Cloonan and John G. Dove challenge librarians to examine how well their libraries reflect Ranganathan's Five Laws of Library Science in the digital age; they focus especially on the online implications of the third law, "Every book, its reader," such as the necessity of making electronic resources as easy to browse as the books on our shelves. ${ }^{9}$

E-books have been in use in some academic libraries for long enough and in great enough numbers to allow for circulation studies. ${ }^{10}$ E-books in those studies have been shown to be used, or at least accessed, at rates sufficient to show their value to collections when compared to print book circulation rates. Another way to measure of the success of e-books is to consider their reception by students; evaluations for one project integrating individual NetLibrary electronic books into selected WebCT courses indicated students were highly receptive to using electronic books, and usage statistics reflected continual use throughout the course. ${ }^{11}$

\section{E-books and the Library Web Site}

There are a number of issues to consider when planning for a successful implementation of e-books through a library's Web site. These points include the placement within the site of pages with links to e-books; what words and phrases will be used to refer to and link to e-books; how well access to e-books is integrated into library catalogs; how easily and in what ways e-books can be searched through sections of libraries' Web sites outside of catalogs; and how to promote the use of e-books through library Web sites.

When librarians and others plan the placement of information resources on Web sites, they generally divide the resources into categories, preferably categories which will seem natural to the users of the site. ${ }^{12}$ In some libraries, e-books are given their own category, while in others they are combined with a mix of types of electronic resources. Different ways to categorize resources also result in variations of how far from the homepage-how many links away-electronic books are located. At some libraries, e-books are linked directly from the homepage, ${ }^{13}$ at others, more clicks are needed to reach e-books. Any resources that are too many layers away from the homepage are likely to be overlooked by patrons. ${ }^{14}$

The words and phrases that highlight and link to electronic books on library Web sites should be easily understood by nonlibrarians. Library jargon should not be a barrier to patrons in locating resources in their own fields of interest. Library Web designers should always choose language 
that will be clear to patrons, even if this requires giving up the ideal of brevity. ${ }^{15}$ The words that patrons find online should match what they expect to find, especially in the basic areas of articles and books. ${ }^{16}$ One study that surveyed undergraduate students in a library skills course found that $39 \%$ or more of students did not correctly understand the terms "catalog" and "collection" in the library context. ${ }^{17}$ Patrons can also encounter difficulty in determining which link on a library homepage leads to a desired resource or service. ${ }^{18}$ One user-centered approach to choosing terminology for Web sites is to find ways to combine a term with specific meaning to librarians with words that are more meaningful to the typical library user, such as "Catalogs of Books \& More."19

E-books should be easily accessible through library catalogs, as one means of ensuring that the virtual library incorporates key values of the traditional library. ${ }^{20}$ Although including e-book records in the library catalog can lead to their increased use, ${ }^{21}$ limiting a catalog search to electronic resources is often a frustrating task for patrons and librarians. Many online catalogs are poorly designed for finding electronic resources only, still featuring jargon-heavy terminology, nonintuitive means of setting limits for a search, and the often false hope of linking to full-text resources. There are varying cataloging practices for the 856 field in MARC - a URL in this field may link to full text or it may link to the table of contents only, depending on what is available and what cataloging request was made. ${ }^{22}$

Unless online catalog access is incorporated through the Web site to an exceptional extent, library catalog links alone do not provide a sufficient means of access to e-books. More dynamic, flexible, and useroriented ways are needed to guide users through the library's electronic collection. ${ }^{23}$ Multiple access routes increase the likelihood that patrons will locate the information they are seeking. ${ }^{24}$ Providing access to e-books outside of the catalog has much in common with providing similar access for electronic journals and other online library resources. Observed patterns for electronic journal access on academic library Web sites include devoting a separate page to electronic journals and/or including electronic journals on more general electronic resources pages. One means of increasing visibility of these resources is to provide either a direct link from the homepage to the electronic journal page or multiple routes to that page from the homepage. ${ }^{25}$ This recommendation can also be applied to Web pages that are devoted to electronic books. While free resources cannot all be considered part of a library's collection, those that have been selected for the online collection should be accessible in the same ways as purchased resources. Organizing online materials by subject may be the approach most useful to library users. ${ }^{26}$

Linking to e-books outside of the catalog allows for more flexibility in presenting e-books as part of thematic packages. This can fit in well with publishers' offerings of aggregated, subject-linked collections. ${ }^{27}$ Purchasing collections of electronic books can also be a better choice for building reference collections than selecting books title by title. ${ }^{28}$ Packages such as Safari Tech Books may be perceived as "collective reference resource[s]" rather than as the means to read specific individual titles. ${ }^{29} \mathrm{To}$ accommodate this type of use, online reference packages may be added to the online catalog and subject guides as packages in addition to their title-by-title coverage. ${ }^{30}$

In spite of the many useful features of e-books, additional promotion of e-books in libraries may be necessary to meet the ideal of "Every book, its reader." Much of this marketing work can be done through library Web pages. ${ }^{31}$ Library publicity efforts to promote e-books have included links, news items, and the use of e-books in instruction sessions. ${ }^{32}$

\section{Methodology}

This study examined 111 academic library Web sites from the Association of Research Libraries (ARL). The purpose of the study was to capture a snapshot 
of the state of access to electronic books across academic library Web sites. No information was collected from the academic libraries regarding the frequency of electronic book usage. A list of questions was created and pretested on twenty
non-ARL academic libraries in November 2004. Characteristics such as the amount of access provided to electronic books through each library's catalog, the means of access to electronic books provided outside of the catalog, and the presence of

\begin{tabular}{|c|c|}
\hline \multicolumn{2}{|c|}{$\begin{array}{c}\text { TABLE } 1 \\
\text { Categories of Data Collected }\end{array}$} \\
\hline Questions Divided by Category & Data Collected \\
\hline $\begin{array}{l}\text { Web Pages Linking to E-books } \\
\text { Does the library Web site have a sec- } \\
\text { tion focusing exclusively on e-books? }\end{array}$ & $\begin{array}{l}\text { - Presence of a Web page that highlights e-books. } \\
\text { - The number of steps from the library homepage } \\
\text { to this section. } \\
\text { - Whether or not the page included individual } \\
\text { e-book titles, e-book packages, or both. } \\
\text { - Whether or not the page included a link to a } \\
\text { search function. }\end{array}$ \\
\hline $\begin{array}{l}\text { Terminology } \\
\text { What terminology is used to describe } \\
\text { e-book sections within the Web site? }\end{array}$ & $\begin{array}{l}\text { - The title of the Web page that highlights e- } \\
\text { books. } \\
\text { - The title of the Web page(s) that contain links } \\
\text { to e-books as well as other electronic resources. }\end{array}$ \\
\hline $\begin{array}{l}\text { Access to E-books in the Library } \\
\text { Catalog } \\
\text { Does the library catalog accommodate } \\
\text { searching for e-books? }\end{array}$ & $\begin{array}{l}\text { The ability to limit a library catalog search to } \\
\text { only electronic resources from the basic/initial } \\
\text { search screen. } \\
\text { - The ability to limit a library catalog search to } \\
\text { e-books with a single step. } \\
\text { - Whether or not the limit actually works. }\end{array}$ \\
\hline $\begin{array}{l}\text { Access to E-books Outside the } \\
\text { Library Catalog } \\
\text { Is it possible to search for electronic } \\
\text { books outside the catalog via the use } \\
\text { of a search mechanism for electronic } \\
\text { resources? } \\
\text { Are individual e-books and e-book } \\
\text { packages included on subject/research } \\
\text { guides? }\end{array}$ & $\begin{array}{l}\text { The types of searches available (e.g., subject, } \\
\text { keyword, title, resource type or category, or a } \\
\text { combination of search types). } \\
\text { - Whether or not the results of the subject search } \\
\text { are the same as the information found on a } \\
\text { subject guide. } \\
\text { The inclusion of individual e-book titles or e- } \\
\text { book packages on subject guides for chemistry, } \\
\text { psychology, and literature. }\end{array}$ \\
\hline $\begin{array}{l}\text { Promotion } \\
\text { How do library Web sites publicize } \\
\text { and promote e-books? } \\
\text { Are e-books included in library in- } \\
\text { struction sessions? }\end{array}$ & $\begin{array}{l}\text { - The presence of local projects for creating or } \\
\text { digitizing e-books. } \\
\text { - Whether or not the library homepage highlights } \\
\text { new e-books. } \\
\text { - Whether or not the e-books page highlights new } \\
\text { e-books. } \\
\text { - The frequency of electronic books mentioned in } \\
\text { current or recently archived library news items. } \\
\text { - Whether or not the library homepage or a train- } \\
\text { ing/instruction page mentions training sessions } \\
\text { that could include the use of e-books. }\end{array}$ \\
\hline
\end{tabular}


elements that promote electronic books to patrons were examined at each Web site. The questions and the data collected for each one are described in table 1.

For questions related to subject searches and subject guides, the disciplines of literature, chemistry, and psychology were chosen as examples. These subjects represent the humanities, sciences, and social sciences and are common to nearly every university curriculum. All questions were answered by direct observation of the library Web sites. Data were gathered between December 2004 and February 2005 and were recorded on an Excel spreadsheet. In addition to the questions, interesting features or innovative approaches related to e-books were also recorded.

\section{Results}

\section{E-books Pages}

Many academic libraries have chosen to highlight e-books on separate pages within the library Web site. Sixty-two (56\%) of the 111 Web sites in this study included a page focusing entirely on e-books. The remaining forty-nine (44\%) Web sites had Web pages that included links to ebooks or e-book packages as part of some broader category of electronic resources. Seven of these forty-nine Web sites had two equally obvious pages that contained links to e-books or e-book packages; in such cases, both pages are included in our analysis. Though these and other sites often had still more pages providing

\begin{tabular}{|c|c|c|}
\hline \multicolumn{3}{|c|}{$\begin{array}{l}\text { TABLE } 3 \\
\text { Steps from the Library Homepage to Other } \\
\text { Main Section(s) Containing Links to E-books }\end{array}$} \\
\hline & Steps & $\begin{array}{l}\text { Number of Pages } \\
\quad(n=56)\end{array}$ \\
\hline $\begin{array}{l}\text { Steps to other section(s) } \\
\text { linking to e-books, if } \\
\text { no e-book page present } \\
\text { (mean } 1.36 \text { ) }\end{array}$ & $\begin{array}{l}0 \\
1 \\
2 \\
3\end{array}$ & $\begin{array}{r}1 \\
37 \\
15 \\
3\end{array}$ \\
\hline \multicolumn{3}{|c|}{$\begin{array}{l}\text { Note: } 49 \text { libraries ( } 44 \%) \text { had other pages that included links } \\
\text { to e-books. } 7 \text { libraries had two equally obvious Web pages } \\
\text { that contained links to e-books. }\end{array}$} \\
\hline
\end{tabular}

\begin{tabular}{|c|c|c|}
\hline \multicolumn{3}{|c|}{$\begin{array}{c}\text { TABLE } 2 \\
\text { Steps from the Library Homepage } \\
\text { to the E-book Page }\end{array}$} \\
\hline & Steps & $\begin{array}{l}\text { Number of } \\
\text { Libraries } \\
(\mathbf{n}=\mathbf{6 2})\end{array}$ \\
\hline $\begin{array}{l}\text { Steps to e-book } \\
\text { page when present } \\
\text { (mean } 1.87 \text { ) }\end{array}$ & $\begin{array}{l}1 \\
2 \\
3 \\
4\end{array}$ & $\begin{array}{r}18 \\
35 \\
8 \\
1\end{array}$ \\
\hline \multicolumn{3}{|c|}{$\begin{array}{l}\text { Note: } 62 \text { libraries }(56 \%) \text { had Web pages devoted } \\
\text { to e-books. }\end{array}$} \\
\hline
\end{tabular}

access to some e-books, these additional pages did not feature e-books.

The number of steps from a library's homepage to Web pages about e-books or other sections containing links to e-books was also counted. (See tables 2 and 3 for a summary of this data.)

For fifty-three (85\%) of the sixty-two libraries with pages devoted to e-books, the e-book page was within two steps (clicks) of the homepage. For forty-seven (96\%) of the forty-nine libraries without Web pages devoted to e-books, the Web page or pages containing links to electronic books were within two steps of the homepage. One library without an e-books page made it possible to search for electronic resources and e-books directly from the homepage, including a search limited to e-books; thus, this site was considered to have a section devoted to e-books that was zero steps away from the homepage.

The contents (e.g., individual e-book titles, e-book packages) of the sixty-two pages that focused exclusively on e-books were also studied. (See table 4.)

Individual titles such as the Oxford English Dictionary, CRC Handbook of Chemistry \& Physics, and Current Protocols were noted. It was more common for the e-book pages to list ebook packages. Packages such as NetLibrary, Oxford Reference Online, CogNet, and Safari Tech Books appeared frequently. The 


\begin{tabular}{|l|c|}
\hline \multicolumn{2}{|c|}{ TABLE 4 } \\
\hline \multicolumn{2}{|c|}{ Contents of the 62 Web Pages Devoted to E-books } \\
\hline \hline & $\begin{array}{c}\text { Number of Sites with } \\
\text { Feature (n = 62) }\end{array}$ \\
\hline Links to individual e-books & $26(42 \%)$ \\
Links to e-book packages & $55(89 \%)$ \\
Links to both individual e-books & $24(39 \%)$ \\
$\quad$ and packages & $16(26 \%)$ \\
Search function or link to a & \\
search function for e-books & \\
\hline
\end{tabular}

e-books and e-book packages tended to be listed in alphabetical order; sometimes they were grouped by subject. Only sixteen $(26 \%)$ of these e-books pages contained or linked to a search function for e-books.

\section{Terminology Used for E-books and E-re- sources}

Librarians have an easy time avoiding specialized jargon to describe electronic books. As a recent OCLC survey confirmed, "Book' is the library brand." 33 "Electronic" is certainly a common term and its abbreviation to "e[-]" is ubiquitous on the Web. Nonetheless, there was still variation in the terminology used in the titles of pages devoted to e-books. Table 5 shows the number of occurrences of the most common words appearing in the titles of e-book pages: "E-Book[s]," "Electronic Book[s]," "Electronic Text[s]," and "E-Texts."

Only one page title used none of these terms: "Databases-Content Type: Book." However, the text of the link leading to this page was the more straightforward "E-Books-Electronic books and texts." Fourteen pages had titles that used some redundancy in wording to describe the page content, such as "eBooks-Online Books and References." There were numerous variations in how the word "E-Book" was presented-whether or not the hyphen was used, and whether the " $\mathrm{E}$," the " $\mathrm{B}$," both, or neither was capitalized; six of the eight possible combinations appeared at least once. Only eight page titles did not use some form of the word "book," and all of those included "E[lectronic] Text[s]."

The most common words in titles of pages that included links to ebooks along with links to other electronic resources were "Databases," "Reference," "Resources," “Electronic" or "E-" and "Full Text." (See table 6.)

Many of these terms were combined in various ways, such as "Electronic Resources," "Electronic Reference," "Reference Resources," and "Full Text Databases." Only six page titles in this group used none of these terms.

\section{Searching for E-books in Library Catalogs} This study also examined whether or not it was possible to limit a catalog search to electronic books or to electronic resources more generally. Ninety-four libraries $(85 \%)$ provided a means for limiting a catalog search to electronic resources. In some catalogs, this limit could be set on the basic search or keyword search screen, while others presented this option only on the advanced search or additional limits screen. (See table 7.)

The next question of interest was whether it was possible to limit a catalog search to e-books. We quickly realized that many library catalogs required two limits to be set for such a search, in most cases requiring the advanced search feature of the catalog. Often, both a format or material type and a location limit had to be selected. These are some of the limit combinations that successfully resulted

\begin{tabular}{|c|c|}
\hline \multicolumn{2}{|c|}{$\begin{array}{c}\text { TABLE } 5 \\
\text { Terminology Used in the Titles of the } \\
62 \text { Pages Devoted to E-books }\end{array}$} \\
\hline Term Used in Title & $\begin{array}{c}\text { Number of Pages } \\
\text { Using Term }(n=62)\end{array}$ \\
\hline E-Book[s] & $26(42 \%)$ \\
\hline Electronic Book[s] & $26(42 \%)$ \\
\hline Electronic Text $[\mathrm{s}]$ & $10(16 \%)$ \\
\hline E-Texts & $8(13 \%)$ \\
\hline
\end{tabular}


in the retrieval of electronic books in different catalogs:

- "Format: Book" and "Location: Electronic Resources"

- "Material Type: Book" and "Electronic Resource: Internet Resource"

- "Material Type: Books" and "Location: Internet Access"

- "Format: Books" and "Medium: Electronic Resources"

Given the confusing and often bewildering array of limit choices, we surmised that most library patrons will not take the time to set two search limits to find e-books. Thus, we considered only the number of catalogs that required just one step to limit the search to e-book results (i.e., those catalogs for which "electronic book" or "e-book" was available as a limit choice on some catalog page). Thirty-three (30\%) of the 111 library catalogs allowed limiting search results to e-books with a single step. In twenty-eight of these catalogs, this limit was present on the basic search screen or as an option on a standard advanced search screen. The remaining five catalogs were slightly different. Three library catalogs included a search screen specifically for electronic resources. These specialized catalog pages were titled "Internet Resources," "Electronic Publication," and "Digital Resources," and when the format type "Book" was selected, the search results included e-books. Two more library catalogs allowed for choosing a search screen just for electronic books searches.

To test whether the e-book limit worked, common keywords such as encyclopedia, science, chemistry, and psychology were searched in each catalog. The level of success of these searches varied. In seventeen (52\%) of the thirty-three catalogs that offer

\section{TABLE 6}

Terminology Used in the Titles of the 56 Pages Including Links to Ebooks but Not Devoted to E-books

Term Used in Title Number of Pages Using Term ( $\mathbf{n = 5 6 )}$

\begin{tabular}{|l|l}
\hline Databases & $21(38 \%)$
\end{tabular}

Reference $\quad 19(34 \%)$

Resources $\quad 13(23 \%)$

Electronic or E- $\quad 13(23 \%)$

\begin{tabular}{l|l} 
Full Text & $8(14 \%)$ \\
\hline
\end{tabular}

single-step e-book searching, results were mainly successful, with most if not all of the hits proving to be actual e-books. Eight $(24 \%)$ catalogs found nothing when the e-book limit was combined with the keywords, although known e-books could be found by a title search. In two more catalogs (6\%), a search limited to "E-books and data files" or "EBooks" found no ebooks and instead a mix of microforms, CDs, and print books with the message " 1 copy being processed," implying that the location or status code for those records was in error. For the remaining six (18\%) catalogs, the results included e-books mixed with nonelectronic books, with the e-books being vastly outnumbered. In many of these cases, the only "electronic" feature of an item was the online table of contents linked from the 856 field of the MARC record.

Access to E-books through Web Pages outside of Library Catalogs

These barriers to finding e-books through library catalogs necessitate the provision of access routes to e-books outside of the library catalog. Although relatively few libraries included a search function for

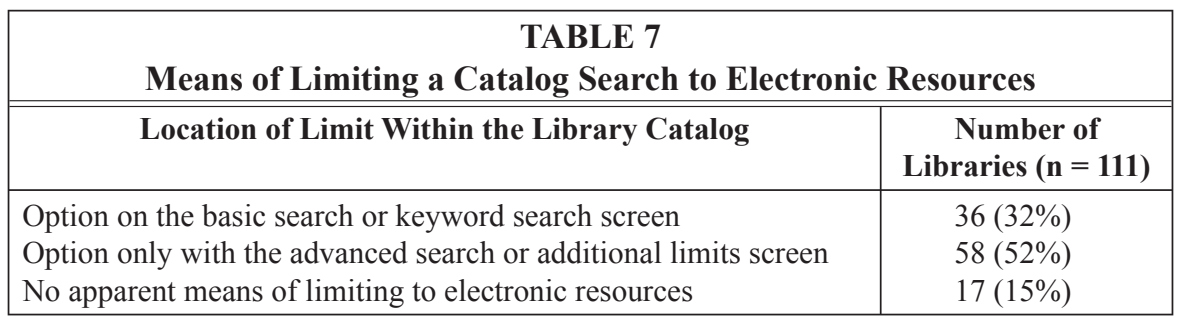


e-books directly on an e-book overview page, most did have ways to search for e-books that were separate from the library catalog. In the pretest examples, this feature was found only as an element of a more general search function for electronic resources, so e-resources searching became the focus of this section of the study. A total of 108 libraries ( $97 \%$ of those surveyed) offered some publicly accessible means for searching for electronic resources outside of the catalog. Two other libraries may have had such a search available, but on a page only visible to users with an institutional password or IP address. Only Ohio State University Libraries did not offer a search for electronic resources outside of their catalog; however, searches of the catalog were integrated throughout that Web site with multiple links and access points, so there was no need for an additional search function. The search functions for electronic resources provided a variety of search options that could include preselected subject listing, exact title, keyword in title, keyword anywhere in the record, type or category of electronic resource, publisher or vendor, or a combination of some of the above. (See table 8.)

There was overlap among which types of keyword searching were available, so that forty-eight libraries (44\%) offered keyword searches of some type for electronic resources outside of the library catalog.

\begin{tabular}{|c|c|}
\hline \multicolumn{2}{|c|}{$\begin{array}{c}\text { TABLE } 8 \\
\text { Search Structures for Electronic Resources } \\
\text { Separate from the Library Catalog }\end{array}$} \\
\hline Search Types Available & $\begin{array}{c}\text { Number of Web } \\
\text { Sites }(\mathrm{n}=\mathbf{1 0 8})\end{array}$ \\
\hline Preselected subject listing & $104(96 \%)$ \\
\hline Exact electronic resource title & $102(94 \%)$ \\
\hline $\begin{array}{l}\text { Keyword } \\
\text { - in title } \\
\text { - anywhere in record }\end{array}$ & $\begin{array}{l}35(32 \%) \\
36(33 \%)\end{array}$ \\
\hline Type or category & $35(32 \%)$ \\
\hline Publisher or vendor & $6(6 \%)$ \\
\hline Combination of some of the above & $16(15 \%)$ \\
\hline
\end{tabular}

Most academic library Web sites offer research guides targeted to major subjects. The authors looked specifically for guides in literature (found on 110 of the surveyed sites), chemistry (found on 106 sites), and psychology (found on 107 sites), in order to have examples from each of the areas of humanities, sciences, and social sciences. To get a sense for how easily e-books on a given subject could be found without using a catalog search, the authors checked for the presence of individual e-book listings and e-book packages on subject research guide pages, as well as among the results of subject browse searches and keyword searches. Again, the examples chosen were the subjects of literature, chemistry, and psychology. Keyword searches were performed for the terms "literature," "literary," and "English"; "chemistry" and "chemical"; "psychology" and "psychological." Searches for "literature" and "English" brought up a number of false hits; these were not counted.

Results varied by discipline, perhaps reflecting variations in the number or affordability of e-books and e-book packages among the three topic areas analyzed. (See figures 1 and 2.)

Because of the varying designs of library Web sites, it was not always possible to keep the results of subject research guide pages and subject browse searches completely distinct. In twelve cases, the only subject research guide to be found was the results page obtained by searching the electronic resources by preselected subject listings. On eight other sites, there was one subject page for each subject, linked from the homepage under a category such as "Research Guides," and also brought up as the result of an e-resources subject search. On another eight sites, a subject search for e-resources led to a page or page section that was a subset of the relevant subject 


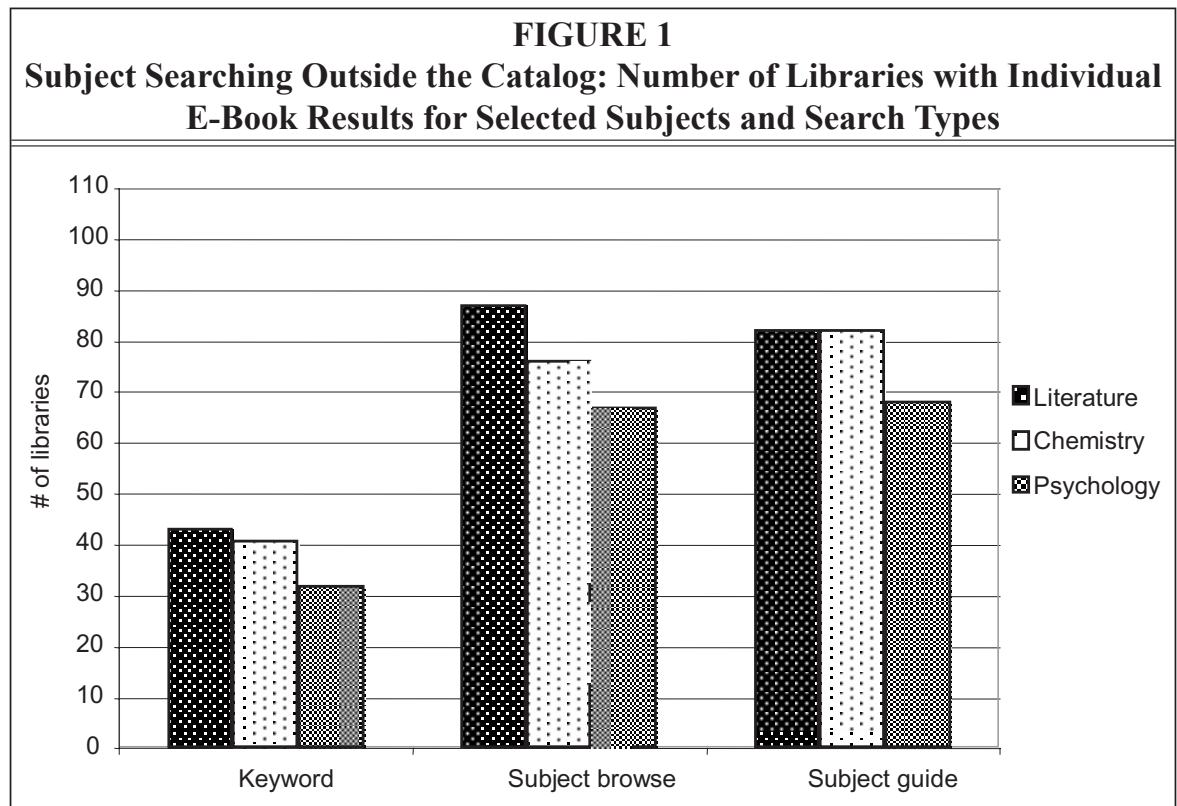

guide. Nine more sites had overlapping results in one or two of the tested subjects but not all three.

Promoting the Use of E-books through Library Web Sites

With many digital initiatives springing up in academic libraries, an obvious point to check was whether the libraries in the study group are creating electronic books, either those that have previously appeared in print or those that are born digital. In December 2004, fifteen (13.5\%) of these libraries had links from their

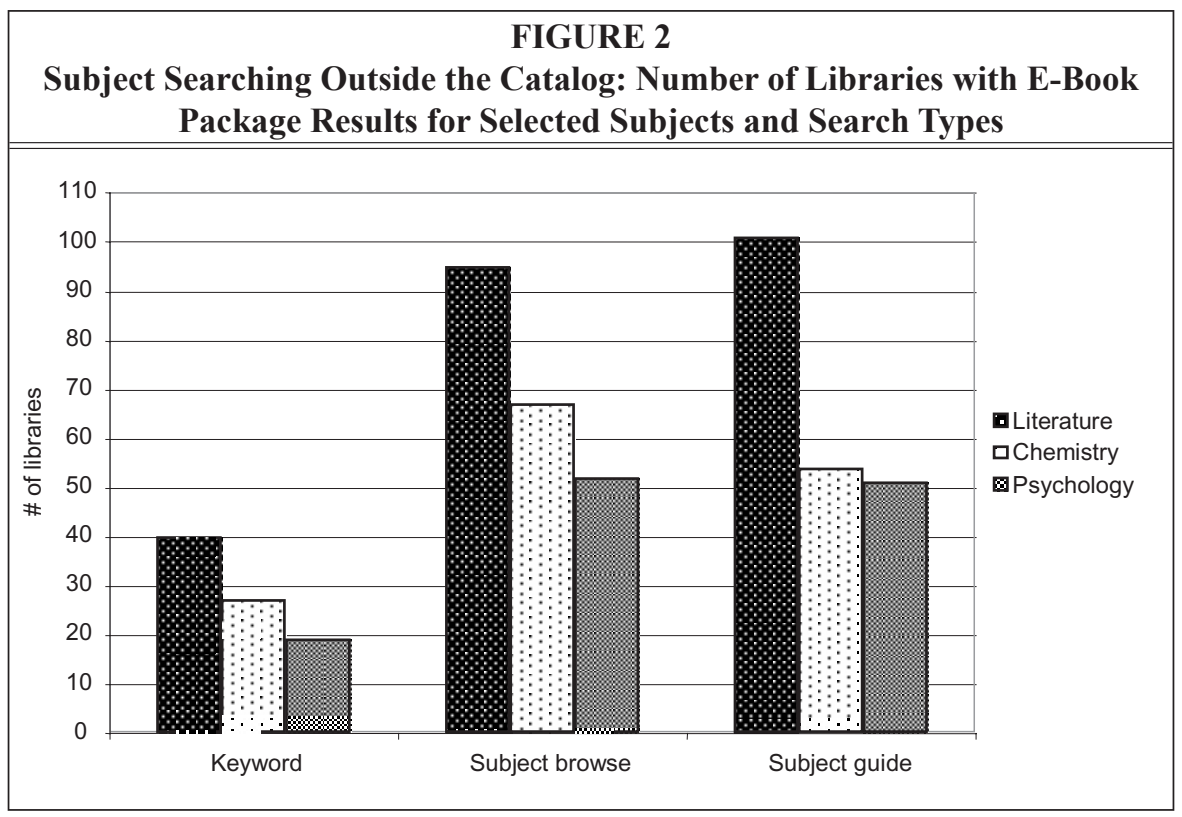


homepages to the pages of local projects for creating or digitizing e-books.

The addition of a new resource of any type is often considered worthy of noting on a library homepage, and electronic books are no exception. When accessed for this study, eleven $(9.9 \%$ ) of the libraries linked from the homepage to a feature or news item focusing on an e-book or e-book package that was not a local digitization effort. Also, eighteen (16.2\%) of the libraries gave special mention on the dedicated e-book page to a new or featured e-book or package.

Recognizing that news items are particularly ephemeral on Web sites, the authors also examined any news archive pages available from library homepages, to check whether news items about ebooks had appeared during the previous six months. Thirty-seven (33\%) of the library Web sites featured only current news items; of these, ten included items about e-books. Sixty-five (59\%) of the Web sites had news archives with dates going back at least six months; of these, thirtyseven had at least one news item about e-books. One site showcased fifteen news items on electronic books. Of the nine $(8.1 \%)$ sites that had dated news archives going back less than six months, six had at least one news item about e-books.

News items and links may reach many of a library's users, but e-books featured in instruction sessions have a better chance of being remembered and used again by learners. Many librarians offering library instruction may have reasons to include e-books. The authors checked libraries' publicly available instruction pages to see if sessions featuring e-books were widely offered. In December 2004, fifteen of the library Web sites (13.5\%) had information on at least one instruction or training session featuring e-books. We repeated these observations in February 2005, finding to our surprise just ten sites $(9.0 \%)$ with information on at least one instruction or training session featuring e-books. Information on library instruction sessions relating to specific university courses was not included in this count, as checking such a large number of course Web pages was beyond the scope of this study.

During the course of the study, the authors also recorded interesting ways in which library Web sites featured or highlighted e-books. Three libraries included direct links from the homepage to frequently used reference e-books, such as the Encyclopedia Britannica and the Oxford English Dictionary. One library included a list of "Top 10 Reference Sources" on the Reference Sources Web page; all of the sources were e-books. One library used the catalog screen to highlight two e-book packages, NetLibrary and Safari. One library provided RSS feeds for "eResources;" e-books were included. The University of Toronto Libraries Web site had provided a search box on the homepage with "e-books" as a search option; but, by the time of this writing, the "e-books" option had been changed to "e-resources." When asked, the Digital Services Librarian responded that the change was made based on usability studies that indicated patrons "did not like having to make a lot of choices before conducting their search." ${ }^{34}$

\section{Discussion}

According to our study, $56 \%$ of the academic library Web sites featured pages devoted to e-books. While this is an excellent way to inform users about the availability of e-books, there proved to be great variation in the content of these pages. Some general observations were noted as the authors recorded whether or not e-book packages or individual titles were included. Some pages were very limited in scope and did not reflect the total e-book holdings of the library. For example, at one library, the page titled "Electronic Books" included only four listings - Early English Books Online, National Academies Press, NetLibrary, and the History E-Book Project. Yet, when e-books were searched using the search feature for electronic resources, other e-books and e-book packages such as the Oxford English Dictionary, CHEMnetBASE, AccessScience, and ENGnetBASE 
were noted in the results. At other Web sites, some e-book pages contained links to mostly literature e-books or packages. Other pages were predominantly literature e-books with a very small number of additional links to packages such as MDConsult and NetLibrary. Some e-book pages were broadly focused and included e-book links for all subjects. Many pages also included links to packages, collections, and directories of free e-books such as the National Academies Press, The Making of America and The Online Books Page.

Based on these observations, it would be beneficial to include the following on Web pages highlighting e-books:

- Include a brief definition or explanation of electronic books. E-books can be single works or bundled in packages. While patrons may be very familiar with searching online indexes available from library Web sites, they may or may not be aware of the availability of electronic books.

- Mention representative titles included in thematic e-book packages containing handbooks or other reference works. Patrons interested in searching the CRC Handbook of Chemistry and Physics may not know the title is part of CHEMnetBASE.

- Provide a statement on the page that advises patrons to check other locations within the library Web site (e.g., the library catalog) if they do not find what they are looking for on the e-books page. Patrons may not know where or how to search for electronic books.

- Include a search function on the page if the e-book list is lengthy.

- Group e-books by subject so patrons do not have to scroll lengthy lists.

- Promote Web sites that offer free e-books. Patrons may not be familiar with freely available e-books and e-book collections available on the Web.

As academic libraries continue to purchase e-books, a logical question arises regarding whether to continue having a separate e-books page. For libraries that have small e-book collections or want to make patrons aware of freely available e-books, it makes sense to include a page that highlights e-books. However, for libraries that are acquiring large numbers of e-books, it may become too time-consuming to maintain a separate page.

Considering the terminology found on the pages devoted to e-books and pages describing electronic resources led us to questions about patrons' understanding of library jargon. For example, one library Web site contained a page titled "E-Books and E-Texts" as well as a page titled "Online Reference Resources." In this example, the former contained links to mostly literary works while the latter contained links to dictionaries and encyclopedias. If patrons were interested in browsing an online encyclopedia, which link would they follow first? Many might describe an online encyclopedia as an e-book.

For patrons and librarians who use an online library catalog to search for e-books, limiting catalog searches to ebooks can be a challenging task. Vendors are not consistent in the ways they implement e-book searching in their catalogs. The following suggestions would improve functionality:

- Provide the option to limit searches to electronic resources or e-books on the basic search or keyword search screen. Based on the results in this study, the limits screen is often buried within the advanced search feature.

- Provide the option to limit searches to e-books with a single step. With current OPACs, it is often necessary to choose two limits, usually one for a format/material type and another for a location/medium.

- Make sure an e-book limit functions properly. There is definite confusion with the 856 field. A URL in this field often linked to the table of contents of a book rather than an e-book.

Although there is certainly room for improvement with regards to catalog functionality, accurate and complete catalog records for electronic books are also important. Robert Bothmann provides specific guidelines for cataloging 
electronic books and urges catalogers to utilize the notes fields and assign genre terms. He asserts that patrons will have an easier time identifying electronic books if catalog records include complete descriptive information. ${ }^{35}$

The limited success in searching for e-books within online catalogs reinforces the notion that e-books should be accessible outside the catalog via some sort of search mechanism. The results of this study showed a variety of features. A number of libraries provided an option to search by type or category of electronic resource. One library provided a drop-down menu for resource type which listed seventeen categories such as "E-books," "Reference Sources \& Tools,"

"Dictionaries and Encyclopedias" and "Full-text." Patrons could select one or more types or select all types, and the search could be combined with a subject search. Combined searches could easily miss important sources-for example, the material type for CHEMnetBASE was "Full-text," so if a patron selected the subject of "Chemistry" and a material type of "Reference Sources \& Tools" or "E-books," CHEMnetBASE would not appear in the results.

Since the data was gathered for this study, a number of libraries have implemented information portals that provide users a means to access all types of electronic resources (e.g., databases, journals, books) outside of the library catalog. Portals allow libraries to manage and provide access to diverse types of information resources. For libraries that do not have the means to implement this technology, consider increasing the functionality of the existing search mechanism by incorporating the following:

- Provide an explanation of what types of resources can be located using this mechanism. If the link on a homepage is entitled "Databases" or "Article Databases and More," provide a brief explanation stating what types of materials can be located. If patrons are looking for electronic dictionaries or encyclopedias, they may not equate these terms with the term "database."

- Provide patrons a variety of ways to search for electronic resources. The use of preselected subject listings allows patrons to quickly glance at the resources for a specific discipline.

- In addition to listing titles alphabetically, provide a search mechanism that allows patrons to search keywords in the title or description.

- If there are multiple choices of search type or category, keep distinctions between them clear.

- Consider how the format and content of separately maintained subject guides is different from the preselected subject listings. It may be possible to combine the two, or preferable to increase the distinctions between the two types of pages.

In addition to including Web pages dedicated to e-books and making e-books "findable" via search mechanisms beyond the online catalog, one of the easiest ways to raise awareness of e-books among library patrons is to use the library homepage to publicize new e-book acquisitions. Many library homepages included links such as "Featured Resources," "E-book of the Month," "Featured Site," or "Electronic Resource of the Month." The University of California-Riverside (http://library.ucr. edu/) prominently displays a link to "Featured Resources." There is a brief description of each resource, accompanied by a small graphic of the e-book cover or logo. The graphics are visually appealing and help draw attention to the resource. The University of Georgia homepage (www.libs.uga.edu/) includes a link to a "Featured Site." There are a number of small graphics that change as the site is refreshed or revisited. At the time the authors collected the data, the featured items included The New Georgia Encyclopedia (www.georgiaencyclopedia.org/), a local digitization project. In addition to the "Featured Resources" type of links, it was noted that while a relatively small number of libraries included links to local e-book digitization projects, many libraries in- 
cluded prominent links on the homepage such as "Digital Projects," "Digital Initiatives," or "Electronic Text Center."

When applicable, librarians should remember to include e-books in library instruction sessions, as this provides another avenue to introduce and publicize e-books to patrons. Although a small number of instruction sessions including e-books were noted in this study, a few libraries were offering sessions such as "E-books: Where to Find Them, How to Use Them" (University of Alberta), "Presenting the 10th Library: The Electronic Library" (University of Florida), and "Online Reference Shelf" (Northwestern University). At the authors' institution, several Gale e-books were acquired at the beginning of fall semester 2005. The Encyclopedia of Bioethics and Grzimek's Animal Life Encyclopedia were promoted and received favorably by students enrolled in first-year English composition courses and a biological evolution course.

\section{Implications for Future Research}

Future studies on e-books in libraries will examine other aspects of the issue. Usability studies that examine how patrons search for electronic books could provide data to inform librarians of the real-world results of Web site design features. Surveys of librarians could address topics such as the priority given to purchases of electronic books in relation to print books, non-Web approaches to informing patrons and potential patrons about e-books, promoting e-books for distance education, or the nature of virtual reference questions involving e-books. Another Web-based study could consider access to free collections of online books from library Web sites. Investigating access to e-books on Web sites of public libraries, or on the sites of more specialized libraries, could yield results useful to librarians working in those or other library types.

\section{Conclusion}

As academic libraries continue to acquire e-books for their collections, it is crucial that library Web sites provide various pathways for easy access. Approaches such as creating Web pages focusing on e-books, including e-books on subject guides, and publicizing new e-books on library homepages are just a few ways to alert patrons to the availability of e-books. Because searching online catalogs for ebooks often has limited success, libraries should strongly consider improving or enhancing the functionality of search mechanisms that are used by patrons to locate all types of electronic resources. Library Web sites should eliminate ambiguity in the terminology used to describe electronic resources. Discerning the differences between categories such as "E-Books and E-Texts," "Online Reference Resources," and "Databases" forces patrons to make choices when seeking information. By providing seamless access to all types of electronic resources, librarians increase the probability that patrons will locate and use the most appropriate resources, whether those are ebooks, e-journals, or databases, to satisfy their information needs.

\section{Notes}

1. Chris Armstrong, Louise Edwards, and Ray Lonsdale, “Virtually There? E-books in UK Academic Libraries," Program - Electronic Library and Information Systems 36, no. 4 (2002): 216-27.

2. Peter Webster, "Implications of Expanded Library Electronic Reference Collections," Online 27, no. 5 (2003): 24-27, 29-30.

3. Dennis Dillon, "E-books: The University of Texas Experience, Part 1," Library Hi Tech 19, no. 2 (2001): 113-24.

4. Karen Coyle, "E-books: It's About Evolution, Not Revolution," Library Journal 128, no. 17 (2003): S8-S12; Karen Schneider, "Search Inside Envy," Library Journal 129, no. 1 (2004): S28.

5. Stephen P. Sottong, "E-book Technology: Waiting for the 'False Pretender'," Information Technology and Libraries 20, no. 2 (2001): 72-80; Coyle, “E-books: It's About Evolution, Not Revolution," S11. 
6. Lucia Snowhill, "E-books and Their Future in Academic Libraries: An Overview," D-Lib Magazine 7, no. 7/8 (Jul./Aug. 2001). Available online at www.dlib.org/dlib/july01/snowhill/ 07snowhill.html.

7. Stuart D. Lee, Electronic Collection Development: A Practical Guide (New York: Neal-Schuman, 2002), 41-97.

8. Chennupati K. Ramaiah, "An Overview of Electronic Books: A Bibliography," The Electronic Library 23, no. 1 (2005): 17-44.

9. Michèle V. Cloonan and John G. Dove, “Ranganathan Online," Library Journal 130, no. 6 (2005): 58-60.

10. Justin Littman and Lynn Silipigni Connaway, "A Circulation Analysis of Print Books and E-books in an Academic Research Library," Library Resources \& Technical Services 48, no. 4 (2004): 256-62; Marilyn Christianson and Marsha Aucoin, "Electronic or Print Books: Which Are Used?" Library Collections, Acquisitions, \& Technical Services 29, no. 1 (2005): 71-81.

11. L. Appleton, "Using Electronic Textbooks: Promoting, Placing and Embedding," The Electronic Library 23, no. 1 (2005): 54-63.

12. Gwen Gregory and M. Marlo Brown, "World Wide Web Page Design: A Structured Approach," Journal of Interlibrary Loan, Document Delivery \& Information Supply 7, no. 3 (1997): 45-59.

13. Stewart M. Brower, "Academic Health Sciences Library Website Navigation: An Analysis of Forty-one Websites and Their Navigation Tools," Journal of the Medical Library Association 92, no. 4 (Oct. 2004): 412-20.

14. Georgia Briscoe, Karen Selden, and Cheryl Rae Nyberg, "The Catalog vs. The Home Page? Best Practices in Connecting to Online Resources," Law Library Journal 95, no. 2 (2003): 151-74.

15. Mark A. Spivey, "The Vocabulary of Library Home Pages: An Influence on Diverse and Remote End-Users," Information Technology and Libraries 19, no. 3 (2000):151-56.

16. Leo Robert Klein, "The Web Is Not Your Library," Library Journal Net Connect (winter 2001): 36-37.

17. Norman B. Hutcherson, "Library Jargon: Student Recognition of Terms and Concepts Commonly Used by Librarians in the Classroom," College \& Research Libraries 65, no. 4 (Jul. 2004): 349-54.

18. Louise McGillis and Elaine G. Toms, “Usability of the Academic Library Web Site: Implications for Design," College \& Research Libraries 62, no. 2 (Jul. 2001): 355-67; Susan Augustine and Courtney Greene, "Discovering How Students Search a Library Web Site: A Usability Case Study," College \& Research Libraries 63, no. 4 (Jul. 2002): 354-65.

19. Ruth Dickstein and Vicki Mills, "Usability Testing at the University of Arizona Library: How to Let the Users in on the Design," Information Technology and Libraries 19, no. 3 (2000): 144-51.

20. Ronald Jantz, "E-books and New Library Service Models: An Analysis of the Impact of E-book Technology on Academic Libraries," Information Technology and Libraries 20, no. 2 (2001): 104-13.

21. Dennis Dillon, "E-books: The University of Texas Experience, Part 2," Library Hi Tech 19, no. 4 (2001): 350-62.

22. Roy Tennant, “The Trouble with Online," Library Journal 129, no. 5 (2004): 26.

23. Kristin Antelman, "Web Lists and the Decline of the Library Catalog," Library Computing 18, no. 3 (1999): 189-95.

24. Briscoe, Selden, and Nyberg, "The Catalog vs. The Home Page?" 162; John Cox, "E-books: Challenges and Opportunities," D-Lib Magazine 10, no. 10 (2004). Available online at www.dlib. org/dlib/october04/cox/10cox.html.

25. Linda A. Rich and Julie L. Rabine, "How Libraries Are Providing Access to Electronic Serials: A Survey of Academic Library Web Sites," Serials Review 25, no. 2 (1999): 35-46.

26. Lesley M. Moyo, "Collections on the Web: Some Access and Navigation Issues," Library Collections, Acquisitions, \& Technical Services 26, no. 1 (2002): 47-59.

27. Webster, "Implications of Expanded Library Electronic Reference Collections," 27.

28. Mick O'Leary, "NetLibrary Rolls Out an Online Reference Collection," Information Today 20, no. 5 (2003): 33, 36.

29. Cox, "E-books."

30. Frances C. Wilkinson, "Would You Like Print with That? Will Electronic Reference Packages Supplant Print?" Against the Grain 14, no. 4 (2002): 1, 18, 20, 22, 24, 26.

31. Jeanie M. Welch, "The Electronic Welcome Mat: The Academic Library Web Site as a Marketing and Public Relations Tool," The Journal of Academic Librarianship 31, no. 3 (2005): 225-28.

32. Snowhill, "E-books and Their Future in Academic Libraries."

33. Cathy De Rosa, Joanne Cantrell, Dianne Cellantani, Janet Hawk, Lillie Jenkins, and Alane Wilson, Perceptions of Libraries and Information Resources: A Report to the OCLC Membership (Dublin, Ohio: OCLC, 2005), 3-1. Available online at www.oclc.org/reports/2005perceptions.htm.

34. Sian Meikle, e-mail message to authors, September 15, 2005.

35. Robert Bothmann, "Cataloging Electronic Books," Library Resources \& Technical Services 48, no. 1 (Jan. 2004): 12-19. 